\title{
ABSTRACTS
}

\section{Federal Democracy in India and the European Union: Towards Transcontinental Comparison of Constitutional Law}

\author{
By Philipp Dann, Gießen
}

India and the EU face a similar challenge: how to democratically govern a polity of continental dimensions and confusing heterogeneity? This question forms the core of this paper, yet it starts one step before. Acknowledging how unusual (and untested) the comparison between the Indian nation-state and the supranational EU is, the paper first discusses whether it is at all possible to compare these two polities - and what methodological challenges this will entail. Concluding nevertheless that these challenges can be met, the paper analyzes the structure and evolution of Indian federalism and federal democracy since independence in 1947. On this basis, it compares the Indian model of federal democracy with that of the EU - and observes two distinctly different approaches. While the Indian model is one of electoral federalism where federalism takes place at the ballot box as regional parties voice local and regional interests and vie for seats in the central parliament, the European model is rather one of executive federalism where regional interest representation is delegated to state governments which are represented in a second chamber that takes major influence on central level decision-making.

\section{Democracy, Representation, and Self-Rule in the Indian Constitution}

\section{By Pritam Baruah, Kolkata / Nicolas M. Rouleau, Toronto}

India is a union of 28 states and 7 Union Territories. Several of its states and sub-state national communities have since the time of independence complained of inadequate representation in the Union, violating their right to self-rule. There exists persistent resentment against the present constitutional setup. This paper examines the failures and potential of federalism and bicameralism as strategies to promote self-rule in India among sub-state communities and reconcile it with the ideal of equal representation. These two strategies seek to promote the coexistence of diverse communities by meeting the demands of selfrule, while uniting them at the national level. The paper first looks at Indian federalism, and particularly Indian asymmetric federalism. In theory, Indian federalism seeks to promote the value of self-rule. However, in practice, it fails to accomplish its objective. It also creates institutions based on ethnic identities that disproportionately empower sub-state national communities, simultaneously disempowering other individuals and groups. The paper then turns to Indian bicameralism. In its limited design, the Indian upper house does little to reduce the fissiparous tendencies of sub-state communities in India. Moreover, the 
current theory of bicameralism seems to allow little opportunity for bicameralism to address these problems in India. However, bicameralism can be further developed theoretically as an institutional mechanism to foster self-rule among sub-state communities in fractious countries - in effect as a middle ground between the theories of federalism and consociation. Applying this theoretical model in practice to the Indian upper house would have potential benefits. A restructured Indian upper house that represents sub-state national communities equally could increase the ability of these communities to participate meaningfully in their own rule, while remaining within the ideal of proportional representation.

\section{The UN-Convention on the Elimination of Discrimination Against Women - Status and Perspectives in India}

\section{By Despoina D. Glarou, Berlin}

Despite the fact that the United Nations Convention on the Elimination of All Forms of Discrimination against Women (CEDAW) is considered to be one of the most widely signed and ratified international human rights treaties, it seems that its implementation is confronted with significant problems. In particular, tensions arise between the endorsement of women's rights and the culture and tradition of each Member State. This may lead to different interpretations of women's rights according to each cultural background (cultural relativism), at the expense of universality of human rights. This tension is illustrated by the considerable number of reservations to the Convention, which impede its actual implementation. In this framework the article focuses on India. Being a relatively early signatory of CEDAW, with a great variety of religions and languages, different traditions and long cultural history, India offers a great example of the dimensions that the implementation of the Convention may have. The article, after examining first the cultural and constitutional background in India, seeks to clarify how the international protection of women's rights and Cultural Relativism interact here. For this purpose the paper discusses the reservations of India to CEDAW and its legal nature. Finally, it outlines the newest developments in India and makes explicit how the culture and legal regimes may determine one another.

\section{The Fading Right to Property in India}

\section{By Gopal Sankaranarayanan, New Delhi}

This paper seeks to analyze the unique position held by property rights in India, and how, by virtue of its recognition in the Constitution of India and its subsequent reproduction in a substantially diluted form, basic tenets of public law and Constitutional interpretation have suffered. While the debate on the right to property has been the basis for much of India's constitutional evolution, particularly with reference to individual freedoms and the limita- 
tions on amendment, the right itself has traversed a wide judicial arc, with grim and possibly irreversible consequences.

\section{The Judiciary and (Labour) Law in the Development Discourse in India}

By Supriya Routh, Kolkata

Amongst the range of development theories available today international institutions promote only a definite development agenda - the neo-liberal development agenda through the invocation of 'rule of law' principle. But, the development agenda so pursued comes in conflict with the actual development (improvement) of the underprivileged and marginalized section of the population. In this essay I argue that rediscovery of the 'rule of law' by Indian judiciary under neo-liberal influence conflicts with the 'support led' development of the marginalized section of the population. Therefore, one agenda of development (i.e., the neo-liberal agenda of development) facilitated by the law is itself an obstacle in the realization of other more direct developmental approaches. In so arguing I refer to the three dominant development theories - sustainable development approach, capability approach and the neo-liberal empowerment approach. I analyse these development approaches in the labour law context of the country to prove my thesis. 